\title{
Effect of Distraction Technique During Immunization to Reduce Behaviour Response Score (FLACC) to Pain in Toddlers
}

\author{
Gedam DS ${ }^{1}$, Verma $\mathbf{M}^{2}$, Patil $\mathbf{U}^{3}$, Gedam $\mathbf{S}^{4}$ \\ ${ }^{1}$ Dr. D Sharad Gedam, MBBS, MD, Associate Professor \\ of Paediatrics, ${ }^{2}$ Ms. Mamta Verma, Principle and \\ Professor of Nursing, LN Nursing College, ${ }^{3} \mathrm{Dr}$. Umesh \\ Patil, MBBS, MD, Assistant Professor of Paediatrics. \\ All from L. N. Medical Colllege, Sarvadharam C sector, \\ Kolar Road, Bhopal, M.P. India and ${ }^{4}$ Dr. Sanjay Gedam, \\ MBBS. (Resident in Pharmacology) RD Gardi Medical \\ College, Ujjain, MP, India.
}

\section{Introduction}

U nfortunately, pain is a natural and unavoidable part of childhood. While most pain is the result of minor scrapes and bruises, there is a very different kind of pain that is associated with the delivery of healthcare. Painful medical procedure is a fact of life. Pain is an unpleasant sensory and emotional experience associated with actual or potential tissue damage ${ }^{1}$. For paediatric patients medical procedure are often painful, unexpected and heightened by situational stress and anxiety leading to an overall unpleasant experience. In spite of its frequency, pain in infant, children and adolescent is often under estimated.

The routine vaccine injections are some of the most common and most painful procedures during childhood especially when they are administered without adopting any pain management practice ${ }^{2,3}$. Uncontrolled pain experience in early period of life has a negative and long lasting effect such as distress ${ }^{4,5}$ and can negatively affect the development of central nervous system ${ }^{6-8}$. Moreover fear and avoidance of medical care during adulthood are partially related to experiences of many painful procedures and fears experienced during childhood. With the continued introduction of new vaccines, children may now receive up to 20 injections by their second birthday 9 . Unfortunately, despite an increased focus on pain assessment and management, infant injection related pain remains largely untreated.

\footnotetext{
Address for correspondence

Dr. D Sharad Gedam

L. N. Medical Colllege, Sarvadharam C Sector,

Kolar Road, Bhopal, M.P. India.

E-mail: sharad_gedam@rediff.com
}

\begin{abstract}
Introduction: Distraction techniques are important non pharmacological tools to reduce pain in infants and children. Few data are available regarding their effectiveness in toddlers. We have assessed effectiveness of audio-visual distraction techniques in toddlers during and after vaccination. Materials and Methods: The study used a quasi experimental three group pretest post test design. For all the three groups, the injections were administered by same staff nurse. Group- 1 (120 Patient) was encouraged to see and play with light and sound producing toy. Group- 2 (120 Patient) children were encouraged to see cartoon movie and children of control group- 3 (110 patient) were immunized without any distraction technique. A question form was used to determine the infant's characteristics and the Face, Leg, Activity, Cry, Consolability (FLACC) Pain Scale was used to assess the level of pain. Data was collected between $1^{\text {st }}$ April 2012 and $30^{\text {th }}$ September 2012. Results: The mean pain score of test group during procedure (Group-1: 2.30 \& Group-2: 3.65) were lower than the score of control group (Group-3: 5.30). Similarly after procedure Score (Group-1: 4.62 \& Group-2: 2.79) were lower than the score of control group (Group-3: 6.20). Conclusion: The lower pain score in response to vaccination in test group indicates that distraction technique i.e. light \& sound producing toys and cartoon movies are practical way to reduce pain during routine medical interventions in toddler.
\end{abstract}

Key words: Distraction, toddler, toys, pain score, immunization.

Various simple methods effectively reduce the pain response of newborns undergoing routine procedures, such as heel lancing. Swaddling, holding, and providing the oral tactile stimulation of sucking on a pacifier are effective non-pharmacologic approaches ${ }^{10-14}$. Oral

\section{How to cite this article?}

Gedam DS, Verma M, Patil U, Gedam S. Effect of Distraction Technique During Immunization to Reduce Behaviour Response Score (FLACC) to Pain in Toddlers. J Nepal Paediatr Soc 2013;33(1):25-30. 
sucrose is an effective pharmacologic analgesic that acts via endogenous opioid pathways ${ }^{15-22}$. The analgesic effect of oral sucrose alone ${ }^{23}$ or combined only with parent holding ${ }^{24}$ has been reported to be limited in infants beyond the newborn period.

Numerous studies have focused on the efficacy of various methods of distracting attention to minimize acute pain in a paediatric population, specially toddler and preschool children such as movies ${ }^{25}$, party blowers ${ }^{26}$, nonprocedural talk ${ }^{27}$, interactive robots ${ }^{28}$, virtual reality goggles $^{29}$, kaleidoscopes ${ }^{30}$, bubbleblowing ${ }^{31}$, short stories $^{32}$ and music ${ }^{33}$ None of these options totally abolishes the pain from injections, but distraction, in general, helps moderately in preschool age and older children ${ }^{34}$.

Regardless of the medical procedure, reducing pain and stress may help children cooperate during the treatment and develop a positive attitude that will benefit both the patient and healthcare provider during future medical experiences. The young patient will have a more positive memory related to the procedure by reducing or alleviating the pain, which will reduce the stress and anxiety. By relieving pain and stress, the healthcare provider faces a less anxious and more cooperative child, resulting in a better medical outcome.

\section{Materials and Methods}

Study design: The study used a quasi experimental three group pre-test post test design.

Setting and Samples: The research was conducted in Out Patient setting of Department of Paediatrics at Tertiary care teaching Institute in Central India from $1^{\text {st }}$ April to $30^{\text {th }}$ September 2012 . It is a tertiary care teaching Hospital in Central India having visit of more than 100 patients in Out Patient Department every day. Orientation about the study topic and procedure was given to staff member including nurse, vaccination clerk and parents. Written consent was obtained from parents to participate in study. The child along with caregiver was taken to immunization room. During the vaccination procedure, the parents of infants in both groups were allowed to calm their babies by touching and talking to them, but not to feed and do anything that would distract the infant's attention (giving toys, showing a dummy, clapping, etc.). Toddler who comes first to the healthcare centre for vaccination were assigned to the test group -1, who came in second place to the centre were assigned to test group -2 and third one to the control group-3. It was lasted in this way. For all the three groups, the injections were administered by same staff nurse. Group- 1 (120 Patient) was encouraged to see and play with light and sound producing toy. Group2 (120 Patient) children were encouraged to see cartoon movie and children of control group- 3 (110 patient) were immunized without any distraction technique.

\section{Exclusion criteria:}

1. Presence of any neurological or chronic disorders.

2. No treatment of any kind received at a healthcare institution before the study.

3. No analgesic medicine taken in the last three hours before the vaccination procedure.

5. Not being accompanied by a parent.

5. Not crying before vaccination procedure.

6. Subcutaneous vaccination i.e. MMR, Chickenpox

Question Form: This form, prepared by the researchers, based on relevant literature, comprised questions to collect participants' demographic data, such as, gender, age, and weight. Information was collected from parents of the children, who had volunteered to participate in the study.

\section{Face, Legs, Activity, Cry, Consolability Pain Scale (FLACC):}

The FLACC is used to assess the behavioural reactions to pain by infants and children (two months to seven years), who cannot express their own pain and with whom oral communication cannot be established ${ }^{35}$. The FLACC pain scale access five behavioural areas (facial expression of the child, the position of the legs, activity, crying, and consolability) with scores ranging from 0 to 2 for each item.

Using the FLACC Pain Scale, the toddler's behavioural reaction to the pain during and after the vaccination was determined in the control and test groups. These responses were coded separately by the researcher and a registered nurse, who was blind to the subject group.

\section{Data analysis:}

In the evaluation of the data, the crying durations of the infants were recorded and scored in seconds, and the pain reaction during and after procedure were scored between 0 and 10, according to the FLACC Pain Scale. For the data analysis, Statistical Package for the Social Sciences (SPSS 11.0) computer program was used. Statistical significance was considered at a $p$ value less than 0.05 .

ANNOVA test is to assess the significance of difference of pre procedure observation between experimental group-1, experimental group-2 and control group-3. Unpaired t-test was used to determine the significance differences of means of distraction technique between the three groups. 


\section{Results}

There were 162 female babies (46.29\%) and 188 male babies (53.71\%) (Table1). Most number of patients came to hospital for DPT booster dose (79.4\%) (Table 2). It may be because of age group we have selected for study (1-3 Years). As per the data of table 2 most of children came for DPT booster dose.

There is significant difference in the behavioural score of group-1 and group-3 ( $t=18.29, p<0.05)$. It indicates that distraction technique i.e. light and sound producing toys are effective to reduce pain in toddler during immunization (Table 3).

There is significant difference in the behavioural score of group-2 and group-3 $(t=9.93, p<0.05)$. It indicates that distraction technique i.e. cartoon movie is effective to reduce pain in toddler during immunization (Table 4)

There is significant difference in the behavioural score of group-1 and group-2 $(t=7.759, p<0.05)$. It indicates that distraction technique i.e. light and sound producing toys are more effective than cartoon movie to reduce pain in toddler during immunization (Table 5).

There is significant difference in the behavioural score of group-1 and group-3 $(t=11.29, p<0.05)$ after immunization. It indicates that distraction technique i.e. sound and light producing toys are effective to reduce pain in toddler even after immunization (Table 6).

There is significant difference in the behavioural score of group-2 and group-3 $(\mathrm{t}=22.73, \mathrm{p}<0.05)$ after immunization. It indicates that distraction technique i.e. cartoon movie is effective to reduce pain in toddler even after immunization (Table 7).

There is significant difference in the behavioural score of group-1 and group-2 $(t=13.35, p<0.05)$ after immunization. It indicates that distraction technique i.e. cartoon movie is more effective than light and sound producing toys to reduce pain in toddler after immunization (Table 8).

Table 1: Frequenting (f) and percentage (\%) distribution of selected variables

\begin{tabular}{|c|c|c|c|c|c|c|c|}
\hline Sr. No. & Variables & \multicolumn{2}{|c|}{ Group I } & \multicolumn{2}{|c|}{ Group II } & \multicolumn{2}{|c|}{ Group III } \\
\hline \multirow[t]{5}{*}{1.} & \multicolumn{7}{|l|}{ Age in months } \\
\hline & & $f$ & $\%$ & $f$ & $\%$ & $f$ & $\%$ \\
\hline & $12-18$ & 79 & 65.8 & 82 & 68.3 & 73 & 66.4 \\
\hline & $19-24$ & 31 & 25.8 & 24 & 20 & 20 & 18.2 \\
\hline & $25-30$ & 10 & 8.4 & 14 & 11.7 & 17 & 15.4 \\
\hline \multirow[t]{3}{*}{2.} & \multicolumn{7}{|l|}{ Sex of Children } \\
\hline & Male & 66 & 55 & 63 & 52.5 & 59 & 53.6 \\
\hline & Female & 54 & 45 & 57 & 47.5 & 51 & 46.4 \\
\hline
\end{tabular}

Table 2: Frequenting (f) and percentage (\%) distribution of vaccines

\begin{tabular}{|l|c|c|c|c|c|c|}
\hline Vaccine & \multicolumn{2}{|c|}{ Group I } & \multicolumn{2}{c|}{ Group II } & \multicolumn{2}{c|}{ Group III } \\
\hline & f & \% & f & \% & f & \% \\
\hline DPT & 98 & 81.7 & 93 & 77.5 & 87 & 79.1 \\
\hline Hepatitis 'B' & 10 & 8.3 & 14 & 11.7 & 9 & 8.2 \\
\hline Others & 12 & 10 & 13 & 10.8 & 14 & 12.7 \\
\hline
\end{tabular}

Table 3: Comparison of Behavioural Response scores in group I \& III during immunization Group I: 120 and Group III: 110

\begin{tabular}{|c|c|c|c|c|}
\hline $\begin{array}{c}\text { Behavioural Response During } \\
\text { Immunization }\end{array}$ & $\begin{array}{c}\text { Standard } \\
\text { Deviation }\end{array}$ & $\begin{array}{c}\text { Mean } \\
\text { difference }\end{array}$ & $\begin{array}{c}\text { Standard Error } \\
\text { mean }\end{array}$ & "t" \\
\hline $\begin{array}{c}\text { Group I (Mean: 2.3) } \\
\text { Group III (Mean: 5.3) }\end{array}$ & 1.24 & 3 & 0.164 & 18.29 \\
\hline
\end{tabular}

Table 4: Comparison of behavioural response (FLACC) \& III during immunization

Group II: 120 and Group III: 110

\begin{tabular}{|c|c|c|c|c|}
\hline $\begin{array}{c}\text { Behavioural response during } \\
\text { Immunization }\end{array}$ & $\begin{array}{c}\text { Standard } \\
\text { Deviation }\end{array}$ & Mean difference & Standard Error mean & " $t$ " \\
\hline $\begin{array}{c}\text { Group I (Mean: 3.650) } \\
\text { Group III (Mean: 5.3) }\end{array}$ & 1.12 & 1.65 & 0.148 & 9.93 \\
\hline
\end{tabular}


Table 5: Comparison of behavioural response (FLACC) in Group I and II during immunization. Group I: 120 and Group II: 120

\begin{tabular}{|c|c|c|c|c|}
\hline $\begin{array}{c}\text { Behavioural response during } \\
\text { immunization }\end{array}$ & $\begin{array}{c}\text { Standard } \\
\text { Deviation }\end{array}$ & Mean difference & $\begin{array}{c}\text { Standard Error } \\
\text { mean }\end{array}$ & "t $"$ \\
\hline $\begin{array}{c}\text { Group I (Mean: 2.30) } \\
\text { Group II (Mean: 3.65) }\end{array}$ & 1.39 & 1.35 & 0.174 & 7.759 \\
\hline
\end{tabular}

Table 6: Comparison of behavioural Score (FLACC) in Group I and III after immunization.

Group I: 120 and Group III: 110

\begin{tabular}{|c|c|c|c|c|}
\hline $\begin{array}{c}\text { Behavioural response during } \\
\text { immunization }\end{array}$ & $\begin{array}{c}\text { Standard } \\
\text { Deviation }\end{array}$ & Mean difference & $\begin{array}{c}\text { Standard Error } \\
\text { mean }\end{array}$ & "t" \\
\hline $\begin{array}{c}\text { Group I (Mean: 4.62) } \\
\text { Group III (Mean: 6.20) }\end{array}$ & 1.07 & 1.58 & 0.14 & 11.29 \\
\hline
\end{tabular}

Table 7: Comparison of Behavioural Response (FLACC) in Group II \& III after immunization

Group II=120 and Group III=110

\begin{tabular}{|c|c|c|c|c|}
\hline $\begin{array}{c}\text { Behavioural response during } \\
\text { immunization }\end{array}$ & Standard Deviation & Mean difference & $\begin{array}{c}\text { Standard Error } \\
\text { mean }\end{array}$ & “t” \\
\hline $\begin{array}{c}\text { Group II (Mean: } 2.79) \\
\text { Group III (Mean:6.20) }\end{array}$ & 1.14 & 3.41 & 0.150 & 22.73 \\
\hline
\end{tabular}

Table 8: Comparison of Behavioural response (FLACC) in Group I and II after immunization.

Group I: 120 and Group II: 120

\begin{tabular}{|c|c|c|c|c|}
\hline $\begin{array}{c}\text { Behavioural response } \\
\text { during immunization }\end{array}$ & $\begin{array}{c}\text { Standard } \\
\text { Deviation }\end{array}$ & Mean difference & Standard Error mean & "t" \\
\hline $\begin{array}{c}\text { Group I (Mean: 4.62) } \\
\text { Group II (Mean: 2.79) }\end{array}$ & 1.06 & 1.83 & 0.137 & 13.35 \\
\hline
\end{tabular}

\section{Discussion}

Immunization becomes a part of children's life. As it protects children from many diseases but it can become stressful for both parents and children. Distraction techniques are effective, easy, and economical and needs no special training.

Previous studies addressing non pharmacological methods, such as parental holding, sucrose, and breastfeeding, confirmed pain reduction in infants when they were subjected to painful procedures. Pain reduction was also reported in previous studies when using various distraction methods in American children during vaccination ${ }^{38,39}$ and during other injection procedures $^{32}$ as well as in American infants during vaccination ${ }^{40,41}$. Finding of our study indicates that distraction technique i.e. light and sound producing toys and cartoon movies are effective in reducing pain during and after immunization. Results are comparable with other studies ${ }^{40,41}$. It has been reported that distraction strategies that use two senses (visual with audio) appears to be more effective in reducing pain than the use of either one alone; and content, intensity, and combinations of multisensory stimuli are important elements of distraction interventions ${ }^{42}$.

\section{Conclusion}

In conclusion, light and sound producing toys and cartoon movies with both visual and auditory elements is a validated and reliable observational measure and a practical way of distracting infants from vaccination pain. It can be regularly used to reduce pain during the vaccination procedure.

Limitations of this study; First, variables such as pain score and crying durations were subjective and based on observational measures. Physiological indices (e.g., heart rate, blood pressure and oxygen saturation) could have been assessed to more accurately determine this factor. Secondly there is difficulty in managing behaviour of parents during vaccination .Parents of control groups are more comfortable during study which may be contributory factor for toddler's anxiety and pain $^{43}$.

Acknowledgements: We thank the parents of the children who participated in the study and the physicians, nurses, and healthcare workers employed at the Institute.

Funding: Nil

Conflict of interest: None 
Permission of IRB: The study is permitted and validated by institutional research board.

\section{References}

1. International association of study of pain (IASP) subcommittee on taxonomy 1979. Pain Terms: A list with definitions and notes on usage. Pain 1979; 6(3):249-52.

2. Felt BT, Mollen E, Diaz S, et al. Behavioral interventions reduce infant distress at immunization. Arch Pediatr Adolesc Med 2000;154:719-24.

3. American Academy of Pediatrics Committee on Infectious Diseases. Recommended childhood and adolescent immunization scheduleUnited States. Pediatrics 2003;111:212-16.

4. Reis EC, Roth EK, Syphan JL, Tarbell SE, Halubkov $\mathrm{R}$, Effective pain reduction for multiple immunization injections in young infants. Arch Pediatr Adolesc Med 2003;157:1115-120.

5. Young KD. Pediatric procedural pain. Ann Emerg Med 2005;45:160-71.

6. Taddio A, Goldbach M, Ipp M,Sterens B, Koren G, Effect of neonatal circumcision on pain responses during vaccination in boys. Lancet 1995;345:291-2.

7. Taddio A, Katz J, llersich AL, Koren G. Effect of neonatal circumcision on pain response during subsequent routine vaccination. Lancet 1997;349:599-603.

8. Gradin M, Eriksson M, Holmqvist G, Holstein A, Schollin J. Pain reduction at venipuncture in newborns: Oral glucose compared with local anesthetic cream. Pediatrics 2002;110:1053-57.

9. American Academy of Pediatrics Committee on Infectious Diseases. Recommended childhood and adolescent immunization schedule_-United States, 2003. Pediatrics 2003;111:212-16.

10. Field T, Goldson E. Pacifying effects of nonnutritive sucking on term and preterm neonates during heelstick procedures. Pediatrics 1984;74:1012-1015.

11. Gunnar MR, Fisch RO, Malone S. The effects of a pacifying stimulus on behavioural and adrenocortical responses to circumcision in the newborn. $J \mathrm{Am}$ Acad Child Psychiatry 1984;23:34-8.

12. Gormally S, Barr RG, Wertheim L, Alkawaf R, Calinoiu N, Young SN. Contact and nutrient caregiving effects on newborn pain responses. Dev Med Child Neurol 2001;43:28-38.

13. Corbo MG, Mansi G, Stagni A, et al. Nonnutritive sucking during heelstick procedures decreases behavioral distress in the newborn infant. Biol Neonate 2000;77:162-67.

14. Bo LK, Callaghan P. Soothing pain-elicited distress in Chinese neonates.Pediatrics [serial online]. 2000;105:e49. Available at: http://pediatrics. aappublications .org/cgi/content/full/105/4/e49.

15. Blass EM, Hoffmeyer LB. Sucrose as an analgesic for newborn infants. Pediatrics. 1991;87:215-18.

16. Haouari N, Wood C, Griffiths G, Levene M. The analgesic effect of sucrose in full term infants: a randomised trial. BMJ 1995;310:1498-500.

17. Stevens B, Taddio A, Ohlsson A, Einarson T. The efficacy of sucrose for relieving procedural pain in neonates: a systematic review and meta-analysis. Acta Paediatr 1997;86:837-38.

18. Overgaard C, Knudsen A. Pain-relieving effect of sucrose in newborns during heel prick. Biol Neonate 1999;75:279-84.

19. Blass EM, Watt LB. Suckling- and sucrose-induced analgesia in human newborns. Pain 1999;83:61123.

20. Stevens B, Yamada J, Ohlsson A. Sucrose for analgesia in newborns undergoing painful procedures [Cochrane Review on CD-ROM]. In: The Cochrane Library, Issue 4, 2001. Oxford, England: Update Software.

21. Abad F, Diaz-Gomez NM, Domenech E, Gonzalez $D$, Robayna M, Feria M. Oral sucrose compares favourably with lidocaine-prilocaine cream for pain relief during venepuncture in neonates. Acta Paediatr 2001;90:160-65.

22. Allen K, White D, Walburn J. Sucrose as an analgesic agent for infants during immunization injections. Arch Pediatr Adolesc Med 1996;150:270-74.

23. Barr RG, Young SN, Wright JH, et al. "Sucrose analgesia" and diphtheria-tetanuspertussis immunization at 2 and 4 months. J Dev Behav Pediatr 1995;16:220-25.

24. Reis EC, Holubkov R. Vapocoolant spray is equally effective as EMLA cream in reducing immunization pain in school-aged children. Pediatrics [serial online]. 1997;100:e5. Available at: http://pediatrics. aappublications.org/cgi/content/full /100/6/e.

25. Cohen LL, Blount RL, Cohen RJ, Schaen ER, Zaff JF. Comparative study of distraction versus topical anesthesia for pediatric pain management during immunizations. Health Psychol 1999;18:591-98.

26. Manimala M, Blount RL, Cohen LL. The influence of parental reassurance and distraction on children's reactions to an aversive medical procedure. Child Health Care 2000;29:161-77.

27. Gonzalez JC, Routh DK, Armstrong FD. Effects of maternal distraction versus reassurance on children's reactions to injections. J Pediatr Psychol 1993;18:593-604.

28. Pringle B, Hilley L, Gelfand K, Dahlquist LM, Switkin $M$, Diver $T$, et al. Decreasing child distress during needle sticks and monitoring treatment gains 
overtime. J Clin Psychol Med settings 2001;8:11930 .

29. Hoffman HG, Patterson DR, Magula J, Corrougher G, Zeltzor K, Dagadakis S, et al. Waterfriendly virtual reality pain control during wound care. J Clin Psychol 2004;60:189-95.

30. Guducu Tufekci F, Celebioglu A, Kucukoglu S. Turkish Children loved distraction: Using kaleidoscope to reduce perceived pain during venipuncture. J Clin Nurs 2009;18:2180-186.

31. Sparks L. Taking the "ouch" out of injections for children : using distraction to decrease pain. $A m \mathrm{~J}$ Matern Child Nurs 2001;26:72-8.

32. Mason S, Johnson MH, Woolley C. A comparison of distractors for controlling distress in young children during medical procedures. J Clin Psychol Med Setting 1999;6:239-48.

33. MacLaren JE, Cohen LL. A comparison of distraction strategies for venipuncture distress in children. $J$ Pediatr Psychol 2005;30:387-96.

34. Uman LS, Chambers CT, McGrath PJ, Kisely S. A systematic review of randomized controlled trials examining psychological interventions for needle related procedural pain and distress in children and adolescents: An abbreviated cochrane review. J Pediatr Psychol 2008;33:824-54.

35. Merkel SI, Voepel-Levis T, Shayevitz JR, Malviys S. The FLACC: A behavioral scale for scoring postoperative pain in young children. Pediatr Nurs 1997;23:29-37

36. Efe E, Özer ZC. The use of breastfeeding for pain relief during neonatal immunization injections. Appl Nurs Res 2007;20:106.

37. Thyr M, Sundholm A, Teeland L, Raham VA. Oral glucose as an analgesic to reduce infant distress following immunization at the age of 3,5 and 12 months. Acta Paediatr 2007;96:23-36.

38. French GM, Painter EC, Coury DL. Blowing away shot pain: A technique for pain management during immunization. Pediatrics 1994;93:384-8.

39. Megel ME, Houser CW, Gleaves LS. Children's responses to immunizations: Lullabies as a distraction. Issues Compr Pediatr Nurs 1998;21:129-45.

40. Cramer Berness LJ, Friedman AG. Behavioral interventions for infant immunizations. Child Health Care 2005;34:95-111.

41. Cohen LL. Reducing infant immunization distress through distraction. Health Psychol 2002;22: 20711.

42. Kline GA. Does a view of nature promote relief from acute pain? J Holist Nurs 2009;27:15966.

43. O'Keefe N. Pain and children. World Ir Nurs 2001; 9:34-6. 